Sharif University of Technology
Scientia Iranica
SCIENTIA
I RAN ICA
http://scientiairanica.sharif.edu

\title{
Influence of masonry panels with openings on the seismic response of reinforced concrete infilled frames
}

\author{
S. Noui ${ }^{\mathrm{a}, *}$, A. Kadid ${ }^{\mathrm{b}}$, and A. Bali ${ }^{\mathrm{a}}$ \\ a. Department of Civil Engineering, Polytechnic National School (ENP-URIE), Avenue des Fréres Ouddak, Hacen Badi, B.P. 182, \\ El-Harrach, 16200, Algiers, Algeria. \\ b. Department of Civil Engineering, UHLB, University of Batna 02, Rue Chahid Mohamed Boukhlouf Batna 5000, Algeria.
}

Received 17 July 2016; received in revised form 15 February 2017; accepted 29 August 2017

\section{KEYWORDS}

Infills;

Openings;

Plastic hinges;

Capacity curves;

Nonlinear layered

shell.

\begin{abstract}
Due to architectural considerations, openings are required in masonry infill panels. In this study, a pushover analysis is carried out to assess the behavior of RC infilled frames with emphasis on the effect of openings on the infills. The main parameters that will be considered concern the size, location, and aspect ratio of the openings. Three reinforced concrete structures representative of rigid, semi-rigid, and flexible structures are designed according to the Algerian seismic code. The numerical model of the structures consists of frame elements with concentrated plastic hinges at the ends and a nonlinear layered shell for the infills. The results obtained show that the presence of infills can drastically change the overall behavior of the structures by enhancing the strength capacities, but with limited ductility, and the presence of openings can modify the locations and patterns of hinges according to their size, location, and aspect ratio.
\end{abstract}

(C) 2019 Sharif University of Technology. All rights reserved.

\section{Introduction}

Reinforced Concrete (RC) frame buildings with masonry infill walls are widely constructed for commercial, industrial, and multi-family residential uses in seismic-prone regions, worldwide, although the masonry infill panels are generally considered as nonstructural components and thus, neglected in assessing the seismic response of reinforced concrete frames. Numerous studies have shown, both experimentally and numerically, that the masonry infill panels can drastically affect the seismic response of reinforced concrete frames and should not be neglected anymore. The existence of the masonry infill panels in a frame

\footnotetext{
*. Corresponding author. Tel.: +2130552 410040 ;

Fax: +213023 82 8535

E-mail addresses: snoui05@yahoo.fr (S. Noui);

abdelkrim.kadid@gmail.com (A.Kadid); balianl@yahoo.fr (A. Bali)
}

doi: $10.24200 /$ sci. 2018.20483 can increase structural strength and stiffness (relative to a bare frame), but, at the same time, interaction should be considered. In general, the presence of the masonry infill panel and interaction with the RC frame change the failure mechanism of the infilled frame in comparison with the bare frame. Masonry is a highly orthotropic material due to the existence of the mortar joint. In addition, the masonry or infill wall can experience different failure mechanisms, such as cracking, sliding, and compression failure. To simulate the behavior of the masonry wall, two types of modeling can be applied, depending on the level of accuracy needed, namely, micro-modeling and macro-modeling. Solid infills have been extensively studied in the last six decades, analytically [1-8], numerically [9-20], and experimentally [21-33]. Compared to RC frames with solid masonry panels, infills with windows or doors have received little attention. Abdel-Gawad et al. (2001) [34] tested ten half-scale models under fully reversed cyclic loading and studied the effect of size and location of openings as well as the interface condition 
between the infill and the frame on strength, stiffness, ductility, energy dissipation, and modes of failure. Their main conclusion consisted of the contribution of infilled frames containing openings, especially framed openings, which should not be ignored, because they improved the stiffness of masonry infill panel under cyclic lateral loads. Goutam et al. (2008) [35] proposed a reduction factor for effective width of the diagonal strut to calculate its initial lateral stiffness when a central window opening was present. They concluded that the presence of central openings could be considered by reducing the effective width through a reduction factor, $\rho w=1-2.6 \alpha C 0$, where $C 0$ is the ratio of the area of opening to the area of the infill; on the other hand, the effect of openings on the initial lateral stiffness of infilled frames should be neglected if the area of openings is less than $5 \%$ of the area of the infill panel. The effect of infill on the initial lateral stiffness of infilled frame may be ignored if the area of opening exceeds $40 \%$ of the area of the infill panel. Sachin and Hemant (2012) [36] carried out a review of the behavior of masonry infill RC frames with openings under inplane lateral load. They stated that the precedent researchers had tried to find out, experimentally and analytically, the influence of several parameters like size, location, and aspect ratio of openings as well as connections between infill and frame. They revealed that the effect of openings was the subject of a large number of experimental and analytical studies all over the world. The masonry infills with openings provide significant amount of stiffness for frames. The failure modes of masonry infilled frames change drastically due to the presence of openings in the wall. The location and size of openings in the infill walls influence deformability, ductility, and energy dissipation capacity. Ephraim and Nwofor (2015) [37] presented a comparative study concerning the composite behavior of multistory RC frames using the macro-model of onestrut configuration and the finite element micro-model. The effect of openings in the infill was specifically concerned. They concluded that introduction of the shear stress reduction factor enhanced the efficiency of the one-strut model to reproduce the shear strength, lateral stiffness, and seismic demand of infilled frames with openings. Cetisli (2015) [38] analyzed the behavior of partly infilled RC frames, taking into account the dimensions and the location of openings. He undertook a numerical parametric study of infilled RC frames with emphasis on wall dimension and locations of openings. He presented an analytical expression for estimating the reduction stiffness of an equivalent diagonal compression strut. Khan and Saim (2015) [39] performed time history analyses on masonry infilled $\mathrm{RC}$ frames and studied the influence of variations of the number of bays, the number of stories, the percentage of opening in the infill wall, the location of the openings, the type of the openings, the number of openings, the infill strength, and the outer frames strength and thickness on the performance of $\mathrm{RC}$ infilled frames. They concluded that the performance of the infilled frames was dependent on the geometric properties of the infill and the frame; on the other hand, with increase in the openings size, the time period, roof displacement, member forces, and interstory drift ratios increased due to the decrease in the lateral stiffness of the structure, whereas infill stresses and base shear force decreased for infilled structures having openings. Maximum infill stresses were found at the corners of the openings, unlike in the fully infilled structures, where the maximum infill stresses were found at the compression corners of the panel.

\section{Description of the structures}

Three structures representing low-, medium-, and highrise reinforced concrete frame buildings with two, five, and ten stories have been used in this study. These structures are designed according to the Algerian seismic code (RPA 2003) [40], to assess the behavior of $\mathrm{RC}$ infilled frames with emphasis on the effect of openings on the infill. The main parameters that will be considered concern the size, location, and aspect ratio of the openings. Four structural configurations with different percentages of openings in the infill have been used, namely, fully infilled, infilled frame with $10 \%$ openings, infilled frame with $25 \%$ openings, and infilled frame with $50 \%$ openings. For location and aspect ratio, six structural configurations with different locations of openings in the infill have been used, namely, central window, left window, right window, central door, left door, and right door, with six structural configurations with different values of aspect ratio. The dimensions of the beams and columns for the three reinforced concrete frames are shown in Figures 1,2 , and 3 . The thickness of the infills is equal to $0.25 \mathrm{~m}$, the typical floor to floor height is $3.00 \mathrm{~m}$, the span between axes of two following columns is $4.40 \mathrm{~m}$, and the details for the beams and columns are shown in Table 1. Material properties are assumed to be $25 \mathrm{MPa}$ for the concrete compressive strength and $400 \mathrm{MPa}$ for the yield strength of the longitudinal and transverse reinforcement steels. The material properties adopted in this study are shown in Table 2.

Table 1. Dimensions of the beams and columns.

\begin{tabular}{lcc}
\hline Building & $\begin{array}{c}\text { Beams } \\
(\mathbf{c m} \times \mathbf{c m})\end{array}$ & $\begin{array}{c}\text { Columns } \\
(\mathbf{c m} \times \mathbf{c m})\end{array}$ \\
\hline Two-story & $30 \times 40$ & $30 \times 30$ \\
Five-story & $30 \times 40$ & $40 \times 30$ \\
Ten-story & $30 \times 40$ & $50 \times 40$ \\
\hline
\end{tabular}



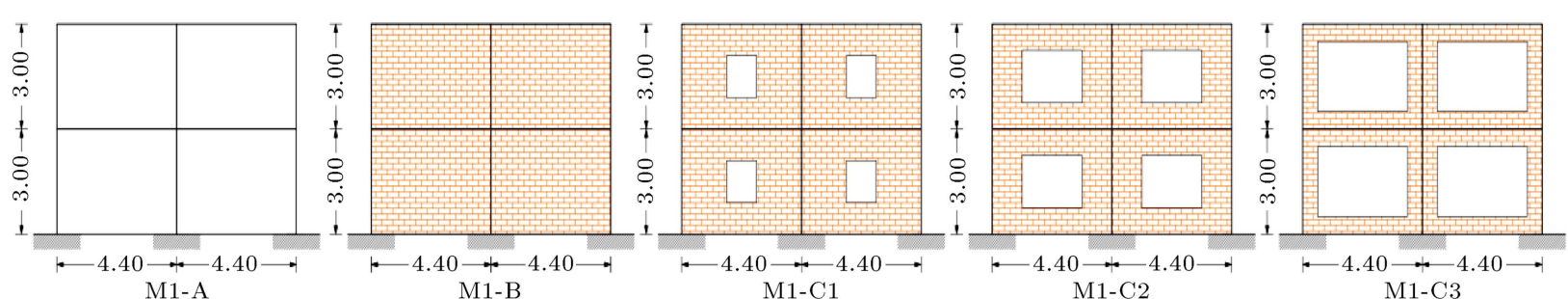

Figure 1. Structure 1 with different percentages of openings in the infill.
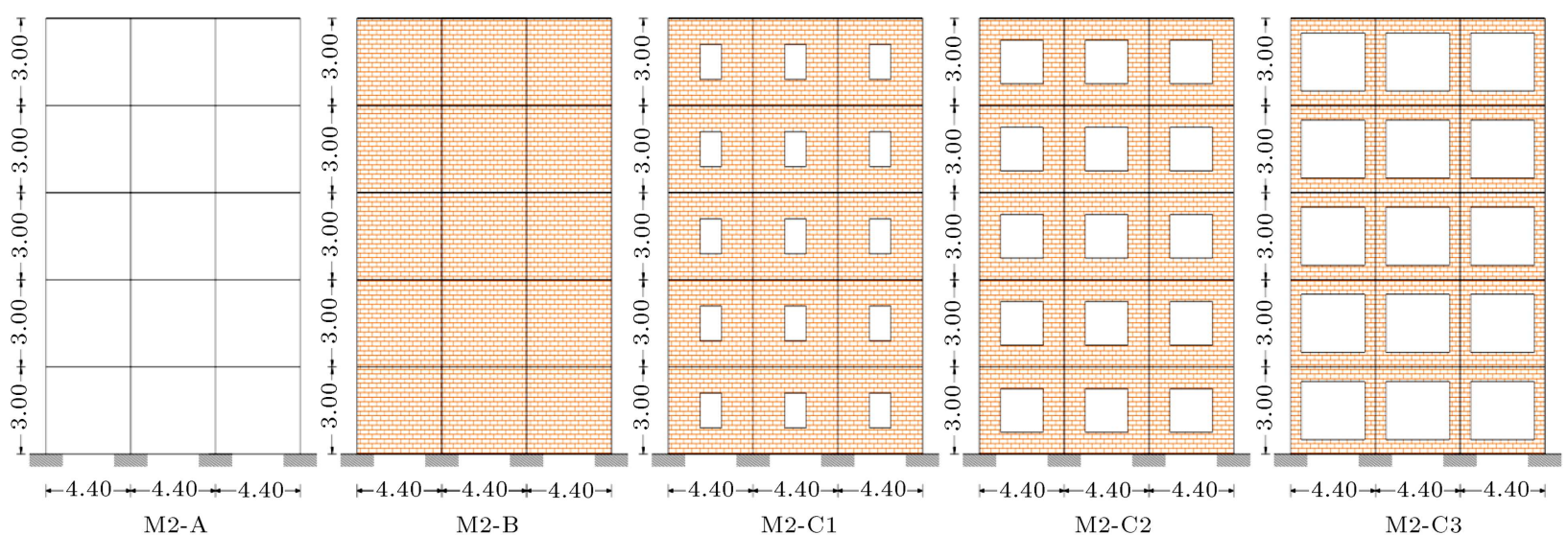

Figure 2. Structure 2 with different percentage of openings in the infill.
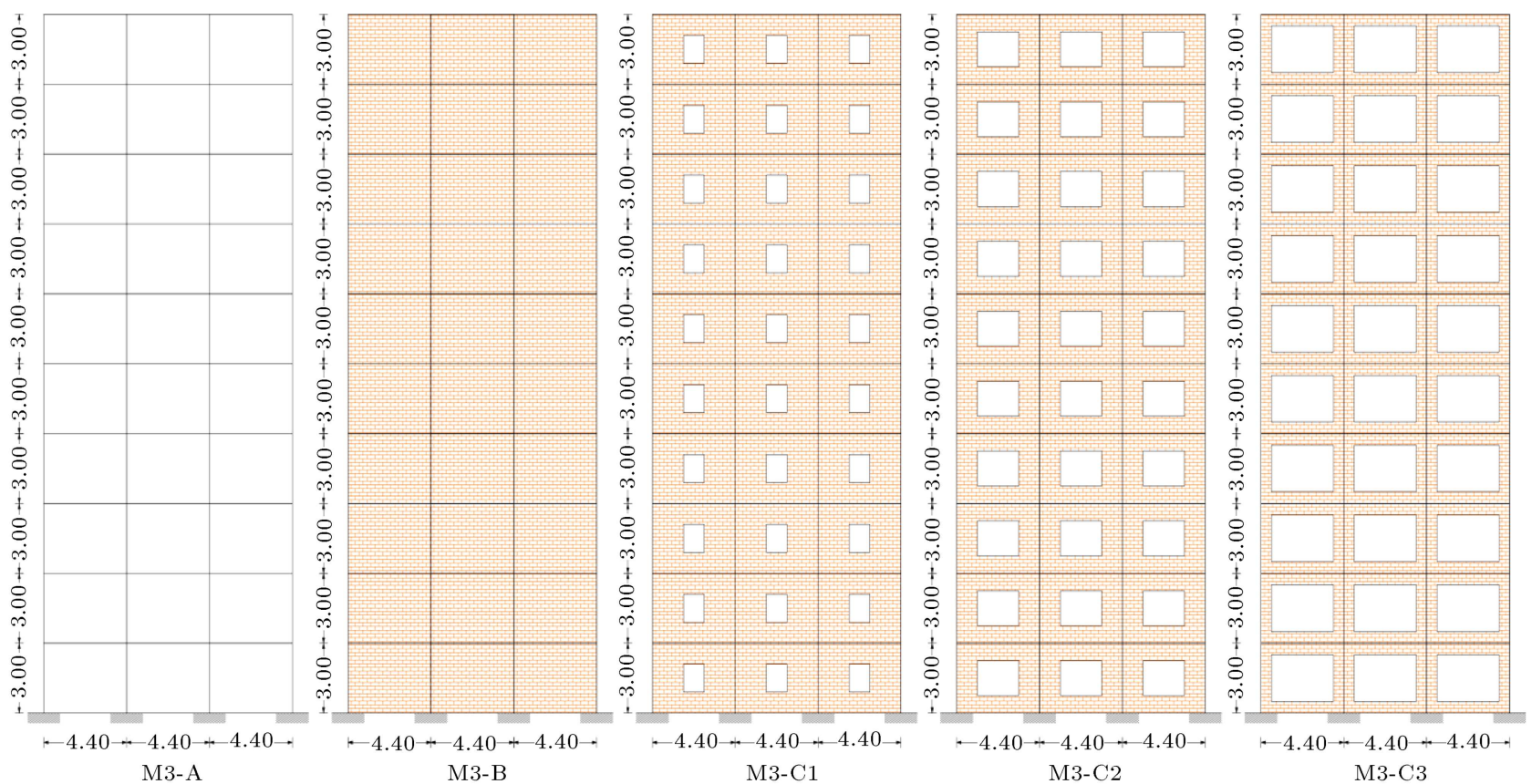

Figure 3. Structure 3 with different percentage of openings in the infill.

\section{Modeling aspects}

A two-dimensional model of each structure is created to perform the nonlinear analysis. Beams and columns are modeled as nonlinear frame elements with lumped plasticity at the start and the end of each element. SAP 2000 [41] provides default-hinge properties, and recommends PMM hinges for columns and M3 hinges for beams as described in FEMA-356 [42]. The infill masonry panels are modeled using a nonlinear layered shell element available in SAP 2000. The layered shell allows any number of layers to be defined in the thickness direction, each with an independent location, thickness, behavior, and material. Membrane 
Table 2. Specification of material properties.

\begin{tabular}{ccc}
\hline Material & $\begin{array}{c}\text { Compressive } \\
\text { strength } \\
\left(\mathbf{k N} / \mathbf{m}^{2}\right)\end{array}$ & $\begin{array}{c}\text { Modulus of } \\
\text { elasticity } \\
\left(\mathbf{k N} / \mathbf{m}^{2}\right)\end{array}$ \\
\hline Concrete & 25000 & 32000000 \\
Masonry & 1100 & 1100000 \\
\hline
\end{tabular}

deformation within each layer uses a strain-projection method presented by Hughes (2000) [43]. In-plane displacements are quadratic. The "drilling" degrees of freedom are not used, and they should not be loaded. These rotations normal to the plane of the element are only loosely tied to the rigid-body rotation of the element to prevent instability. For bending, a Mindlin-Reissner formulation is used, which always includes transverse shear deformations. Out-of-plane displacements are quadratic and consistent with the in-plane displacements. The layered shell usually represents full-shell behavior. Unless the layering is fully symmetrical in the thickness direction, membrane and plate behaviors will be coupled. The section is built-up in the thickness direction. Any number of layers is allowed, even a single layer. Layers are located with respect to a reference surface. According to the SAP 2000 manual, this model should only be used when the infill element is completely surrounded by frame or other supporting elements, and the elements should not be meshed.

The anisotropy of masonry will be modeled by 2 different stress strain curves each of which respectively represents vertical and horizontal stresses S22 and S11, and shear stress S12 (Figure 4). The key to this approach is making prediction, as good as possible, of the stress strain curves for each direction. Here, the S11 and S22 curves will have the same behavior. So far, no tests have been done in perpendicular direction due to the fact that bricks are mounted horizontally in a wall. Also, it is very rare or even impossible to apply a horizontal force to masonry and expect to fail in shear rather than in compression. Although no compression tests exist for the perpendicular di- rection, it is expected that the compression resistance should be higher, because the bricks have a greater percentage and they are stronger than mortar. A rigid full contact connection between frames and infills is adopted.

\section{Pushover analysis}

The Static Pushover Analysis (SPA) procedure has been presented and developed over the last three decades by numerous researchers $[44,45]$. The static pushover analysis method is mainly based on the assumption that the response of the structure is controlled by the first mode or by the first few modes of vibration, and that this shape remains constant throughout the elastic and inelastic responses of the structure. To perform a pushover analysis, a pattern of increasing lateral forces needs to be applied to the mass points of the system. The purpose of this is to represent all forces which are produced when the system is subjected to earthquake excitation. By incrementally applying this pattern up to and into the inelastic stage, progressive yielding of the structural elements can be monitored. During the inelastic stage, the system will experience a loss of stiffness and a change in its vibration period. In this study, uniform lateral forces proportional to story masses are used and gravity loads remain constant. The pushover analysis provides a base shear and roof displacement relationship, called capacity curve or pushover curve (Figure 5).

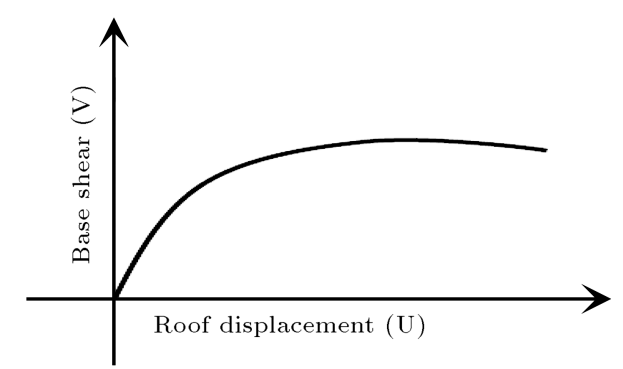

Figure 5. Pushover curve showing the horizontal roof displacement versus the base shear.
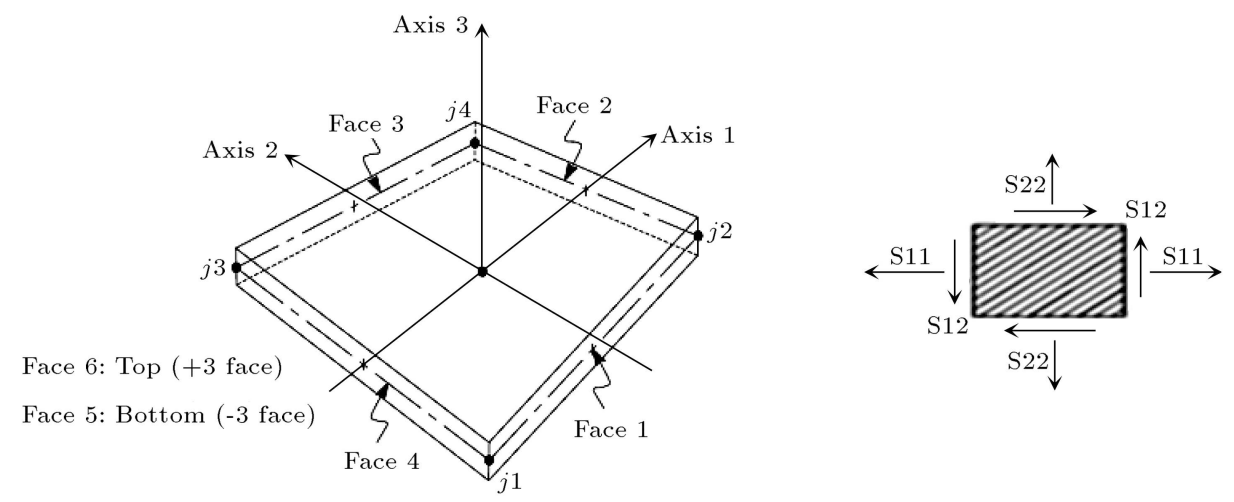

Figure 4. A four-node shell element and in-plane stresses. 


\section{Results and discussions}

\subsection{Effect of openings on the fundamental period}

The fundamental period increases as the size of the infill openings increases, due to the reduction in the lateral stiffness of the structures. For instance, the differences in the fundamental period between the bare frame ( $100 \%$ openings) and the fully infilled frame $(0 \%$ openings) for the three structures are $27 \%, 31 \%$, and $37 \%$ respectively, for percentages of openings of $10 \%$, $25 \%$, and $50 \%$; the rates of increase in the fundamental period compared to the case of $0 \%$ openings are different for each structure, suggesting an influence of the dynamic characteristics of the models. However, the opening size of infill does not have an influence on the participation coefficient (see Table 3).

\subsection{Capacity curves}

The capacity curves for the three structures are shown in Figures 6, 7, and 8. For Structure 1, the strength capacity of the fully infilled frame is increased by $86.74 \%$ compared to the bare frame. With the increase in the percentage of infill openings (from $10 \%$ to $50 \%$ ), the strength capacity of the partially infilled frames is decreased by $7.17 \%, 45.71 \%$, and $68.52 \%$, respectively. The infill wall enhances the lateral stiffness of the frame; however, the presence of infill openings tends to reduce the lateral stiffness. For Structure 2, the percentage difference in strength capacity between the fully infilled and the infilled frames with $10 \%, 25 \%$, $50 \%$, and $100 \%$ (bare frame) openings is $17.31 \%$, $44.26 \%, 72.27 \%$, and $83.64 \%$, respectively. For Struc-

Table 3. Fundamental periods and mass contributions for various percentages of openings.

\begin{tabular}{ccc}
\hline Structure & $\begin{array}{c}\text { Period } \\
(\mathbf{s e c})\end{array}$ & $\begin{array}{c}\text { Mass contribution } \\
(\%)\end{array}$ \\
\hline M1-A & 0.29 & 91.00 \\
M1-B & 0.08 & 90.77 \\
M1-C1 & 0.10 & 89.66 \\
M1-C2 & 0.13 & 86.65 \\
M1-C3 & 0.21 & 88.66 \\
M2-A & 0.57 & 83.24 \\
M2-B & 0.18 & 83.08 \\
M2-C1 & 0.23 & 81.93 \\
M2-C2 & 0.30 & 81.74 \\
M2-C3 & 0.50 & 84.02 \\
M3-A & 1.03 & 79.81 \\
M3-B & 0.39 & 76.56 \\
M3-C1 & 0.52 & 76.90 \\
M3-C2 & 0.59 & 78.68 \\
M3-C3 & 0.73 & 79.47 \\
\hline
\end{tabular}

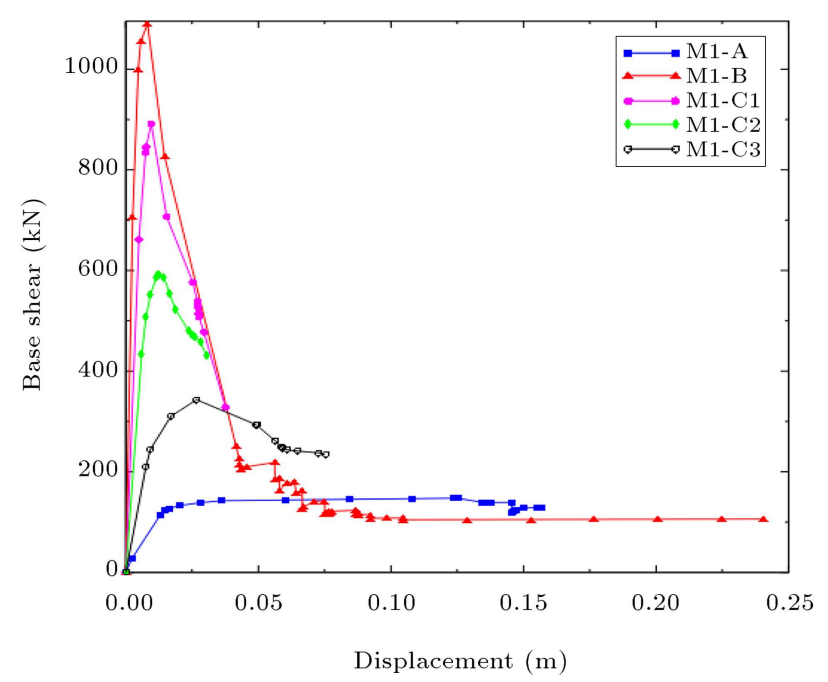

Figure 6. Capacity curve of Structure 1 with different percentages of infill openings.

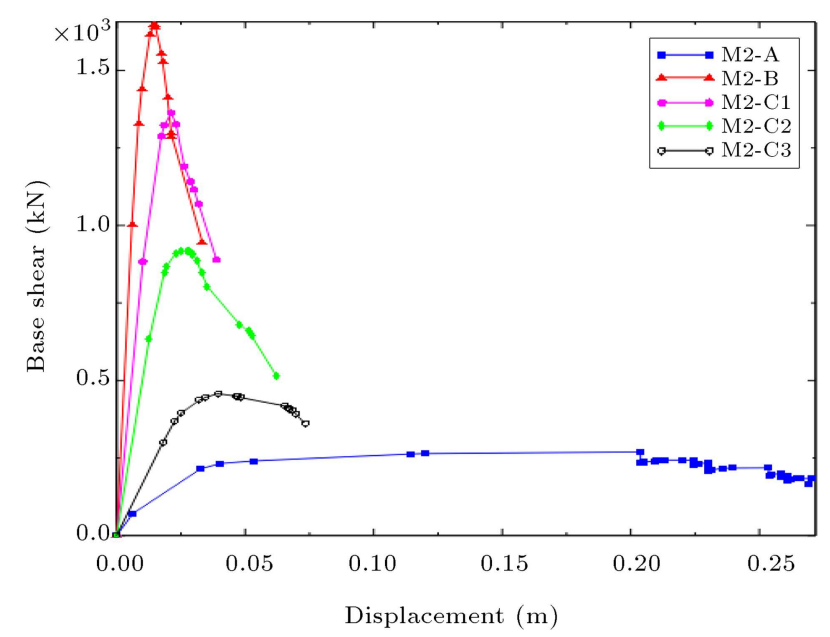

Figure 7. Capacity curve of Structure 2 with different percentages of infill openings.

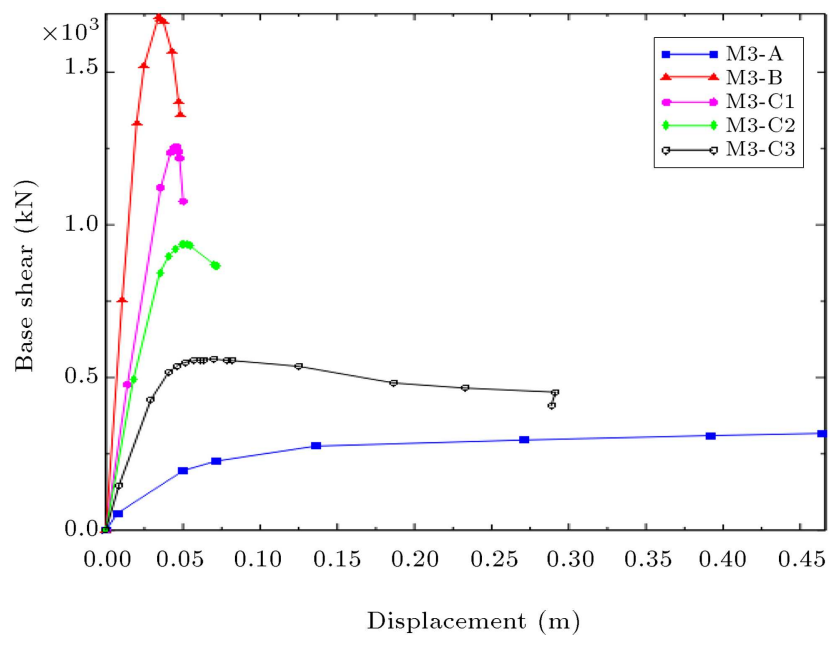

Figure 8. Capacity curve of Structure 3 with different percentages of infill openings. 
ture 3 , the percentage difference in strength capacity between the fully infilled and the infilled frames with $10 \%, 25 \%, 50 \%$, and $100 \%$ (bare frame) openings is $25.37 \%, 44.30 \%, 66.83 \%$, and $81.16 \%$, respectively. Globally, the bare frames exhibit better ductility than infilled frames, which can be explained by the brittle behavior of the masonry infill panels.

\subsection{Effect of locations of different openings}

For this study, six structural configurations with different locations of openings in the infill have been used: central window, left window, right window, central door, left door, and right door (Figures 9, 10, and 11).

The capacity curves for the three structures are shown in Figures 12, 13, and 14. For Structure 1, moving the opening window to left or right results in an increase in the strength capacity compared to a central window, whereas for door opening, the capacity curve is reduced when the opening is moved toward left or right. For Structure 2, however, the percentages of increase are different for the left and right sides; the capacity of the left window opening is greater than that of the central and right openings, which have approximately the same strength capacity. The strength capacities of the central and left door openings are equivalent, while the capacity of the right door opening is reduced. In Structure 3, the capacities associated with the left or right door and window opening are either reduced or increased, suggesting an influence of the dynamic characteristics of the models.

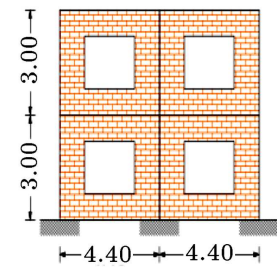

M1-L1

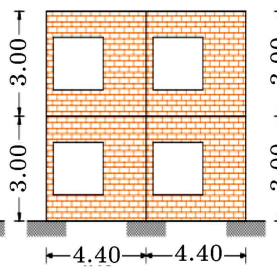

M1-L2

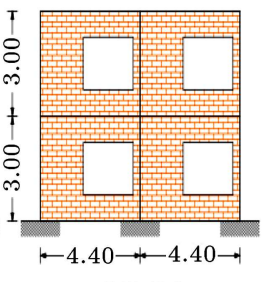

M1-L3

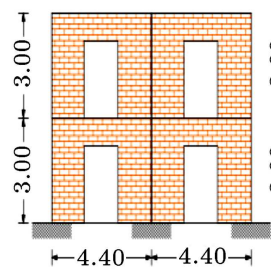

M1-L4

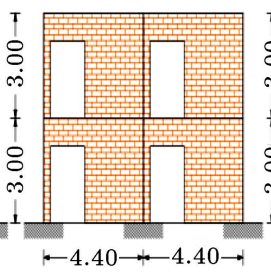

M1-L5

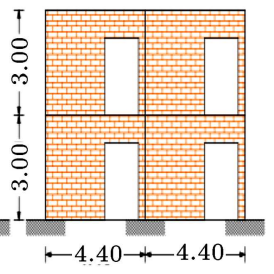

M1-L6

Figure 9. Structure 1 with different locations of $25 \%$ openings.

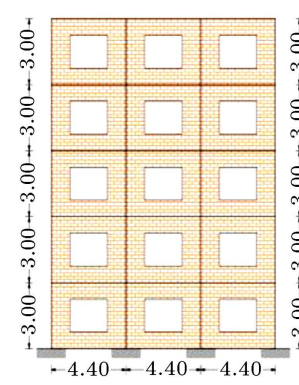

M2-L1

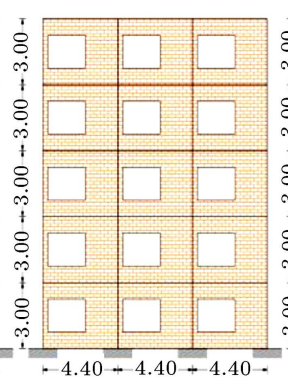

M2-L2

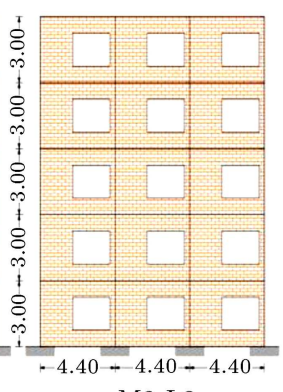

$\mathrm{M} 2-\mathrm{L} 3$

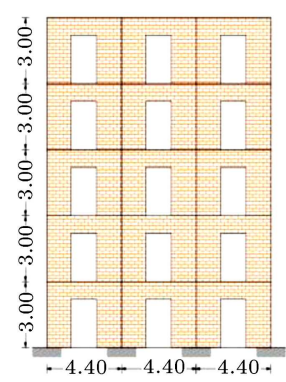

M2-L4

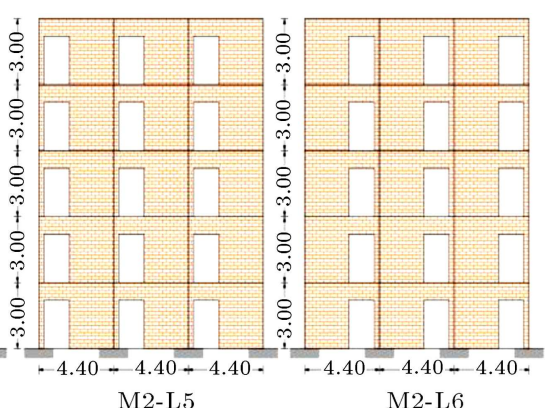

M2-L5

M2-L6

Figure 10. Structure 2 with different locations of $25 \%$ openings.
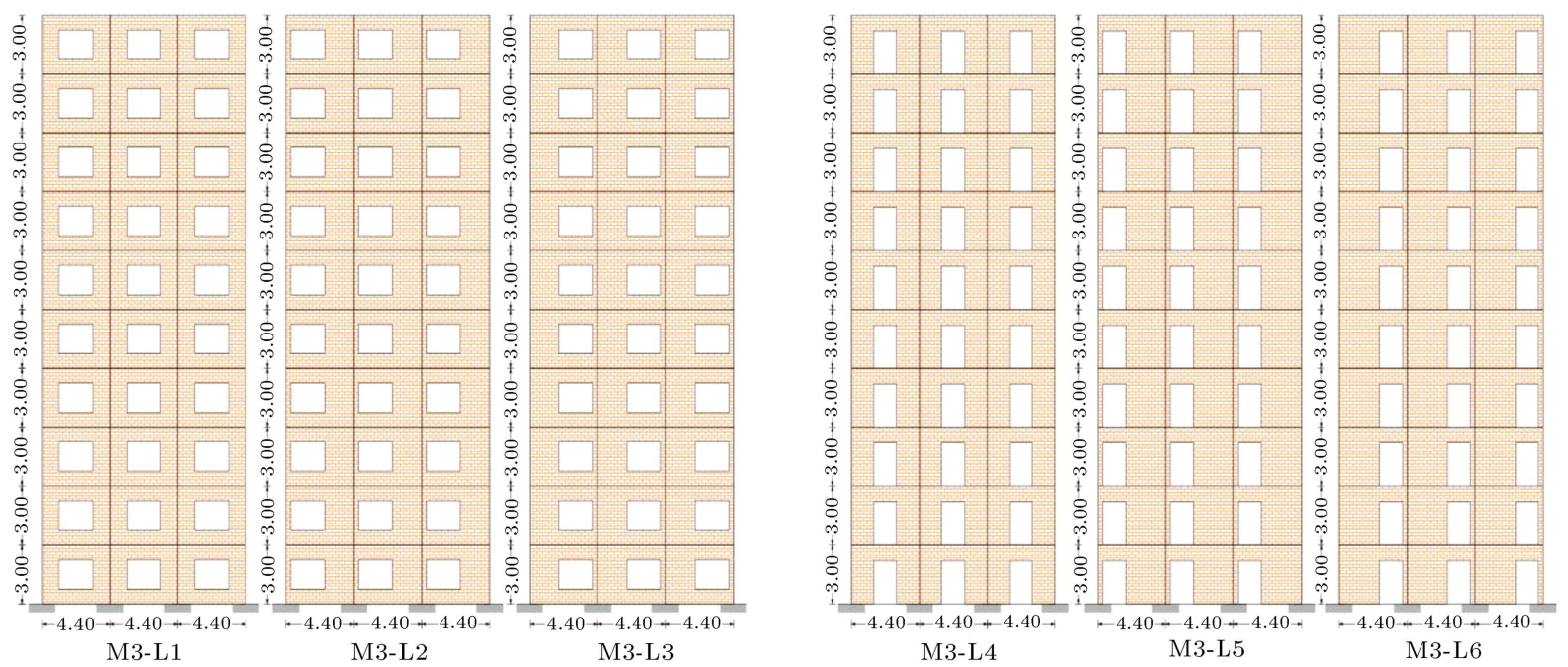

Figure 11. Structure 3 with different locations of $25 \%$ openings. 


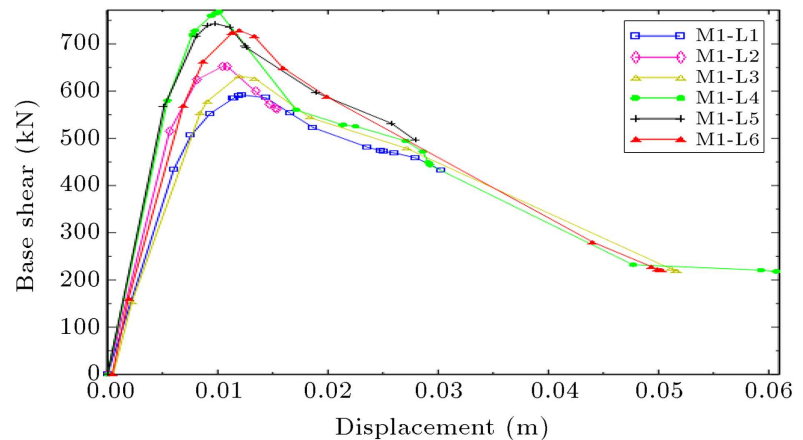

Figure 12. Capacity curve of Structure 1 with different locations of window and door in the infill.

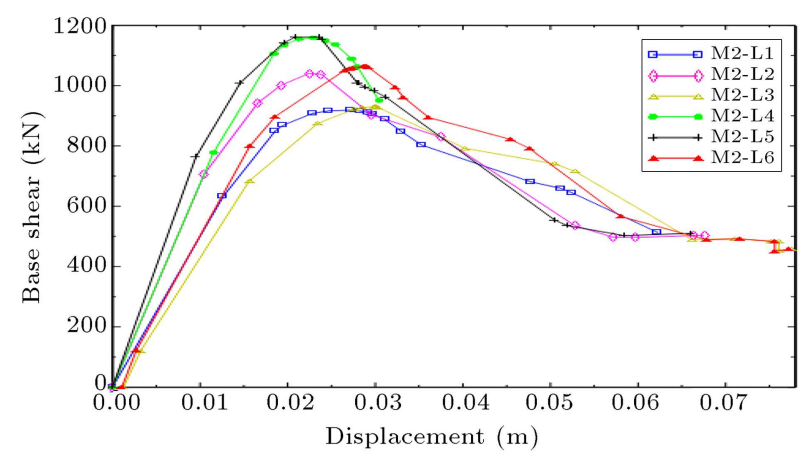

Figure 13. Capacity curve of Structure 2 with different locations of window and door in the infill.

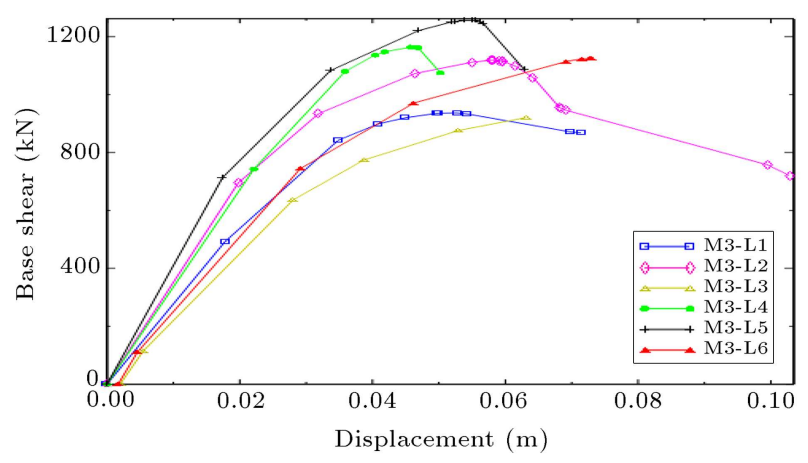

Figure 14. Capacity curve of Structure 3 with different locations of window and door in the infill.

\subsection{Effect of aspect ratio}

To study the effect of aspect ratio, six structural configurations with different values of aspect ratio $H_{o} / B_{o}$ (where $H_{o}$ and $B_{o}$ are the height and the width of the opening) ranging from 0.25 to 1.33 are considered, as shown in Table 4 . In all cases, the area of the opening is kept constant.

The capacity curves for the three structures are shown in Figures 15, 16, and 17. For Structure 1, the strength capacity for an aspect ratio of 0.25 is equal

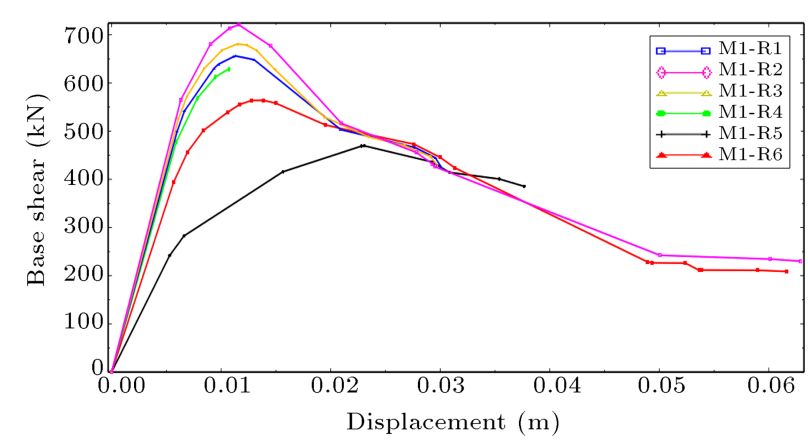

Figure 15. Capacity curve of Structure 1 with different values of aspect ratio $H_{o} / B_{o}$.

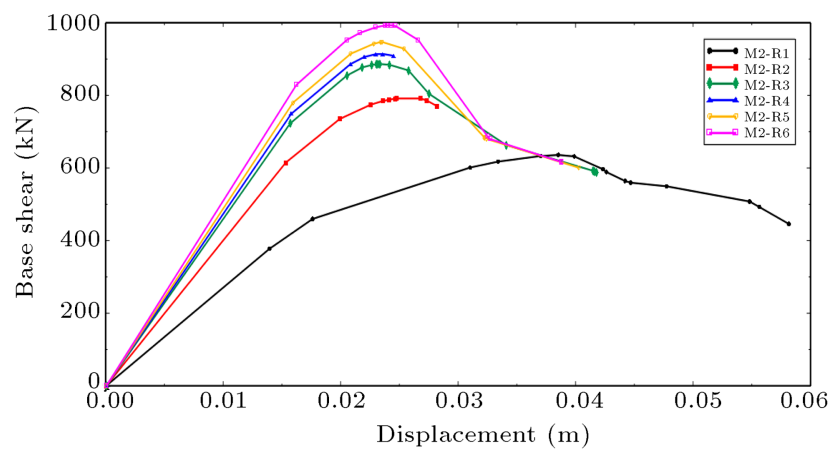

Figure 16. Capacity curve of Structure 2 with different values of aspect ratio $H_{\circ} / B_{o}$.

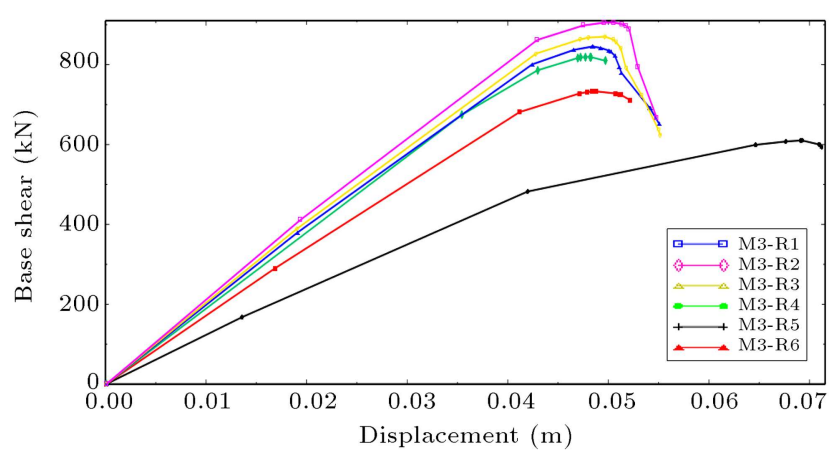

Figure 17. Capacity curve of Structure 3 with different values of aspect ratio $H_{o} / B_{o}$.

to $600 \mathrm{kN}$. The strength capacity is increased by $20 \%$, $34 \%, 39.71 \%, 45 \%$, and $53.48 \%$ for values of aspect ratio equal to $0.5,0.75,0.85,1.0$, and 1.33 , respectively. The same trend is observed for Structures 2 and 3 . This can be explained by the fact that the masonry infill panels with opening behave like a coupled masonry wall and with increase in the aspect ratio, the masonry wall piers will have a larger stiffness, which enhances the bearing capacity of the structures and a coupling

Table 4. Values of aspect ratio $R=H_{\circ} / B_{o}$.

\begin{tabular}{ccccccc}
\hline Cases & 1 & 2 & 3 & 4 & 5 & 6 \\
$\boldsymbol{R}=\boldsymbol{H}_{\text {o }} / \boldsymbol{B}_{\boldsymbol{o}}$ & $R 1=0.25$ & $R 2=0.50$ & $R 3=0.75$ & $R 4=0.85$ & $R 5=1.00$ & $R 6=1.33$ \\
\hline
\end{tabular}


masonry thin beam, resulting in low shear stresses.

\subsection{Plastic hinges mechanisms}

Under gradually increasing loads, some elements may yield sequentially. Consequently, at each event, the structures experience a stiffness change as shown in Figure 18. In the figure, five points labeled A, B, C, D, and $\mathrm{E}$ are used to define the force deflection behavior of the hinge, and the three points labeled IO, LS, and $\mathrm{CP}$ are used to define the acceptance criteria for the hinge. IO, LS, and CP stand for immediate occupancy, life safety and collapse prevention respectively and are defined par FEMA 356.

The hinging patterns are plotted in Figures 19 and 20. The plastic hinges in the bare frames are spread over the height of the structures, whereas in the infilled frames, the plastic hinges tend to concentrate in the lower levels, especially for solid infills and infills with low percentages of openings. The presence of

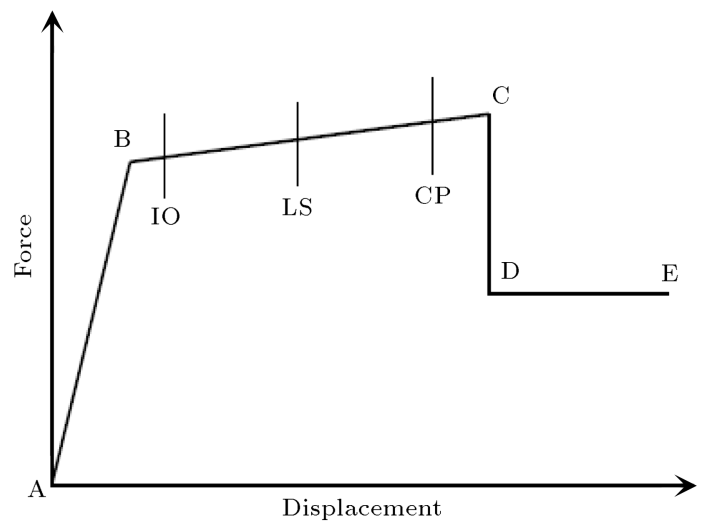

Figure 18. Generalized force-deformation relation for elements or components.

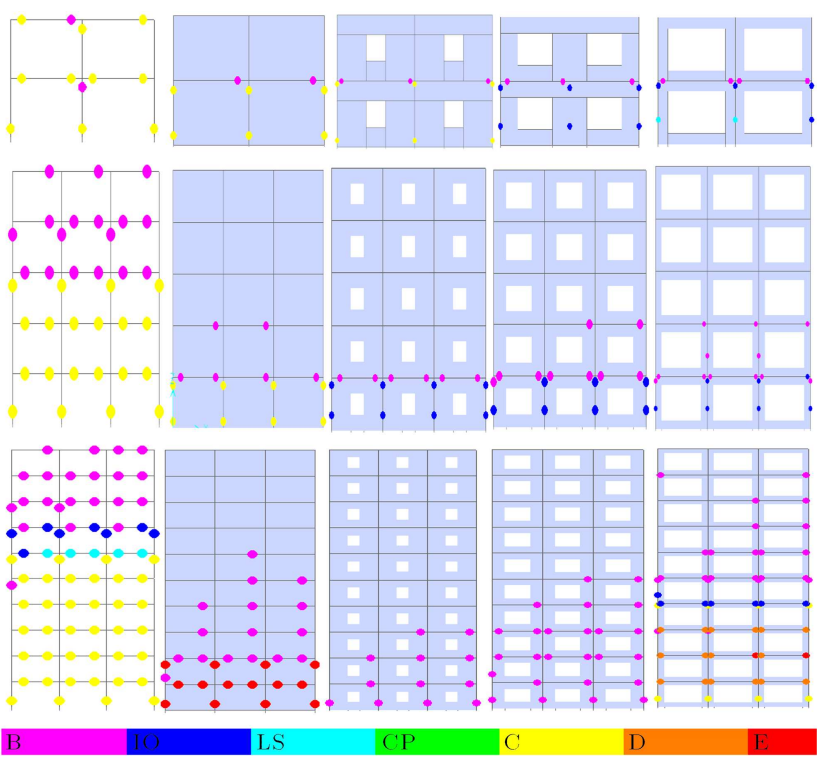

Figure 19. Hinges patterns for Structures 1, 2, and 3 with different percentages of openings in the infill.
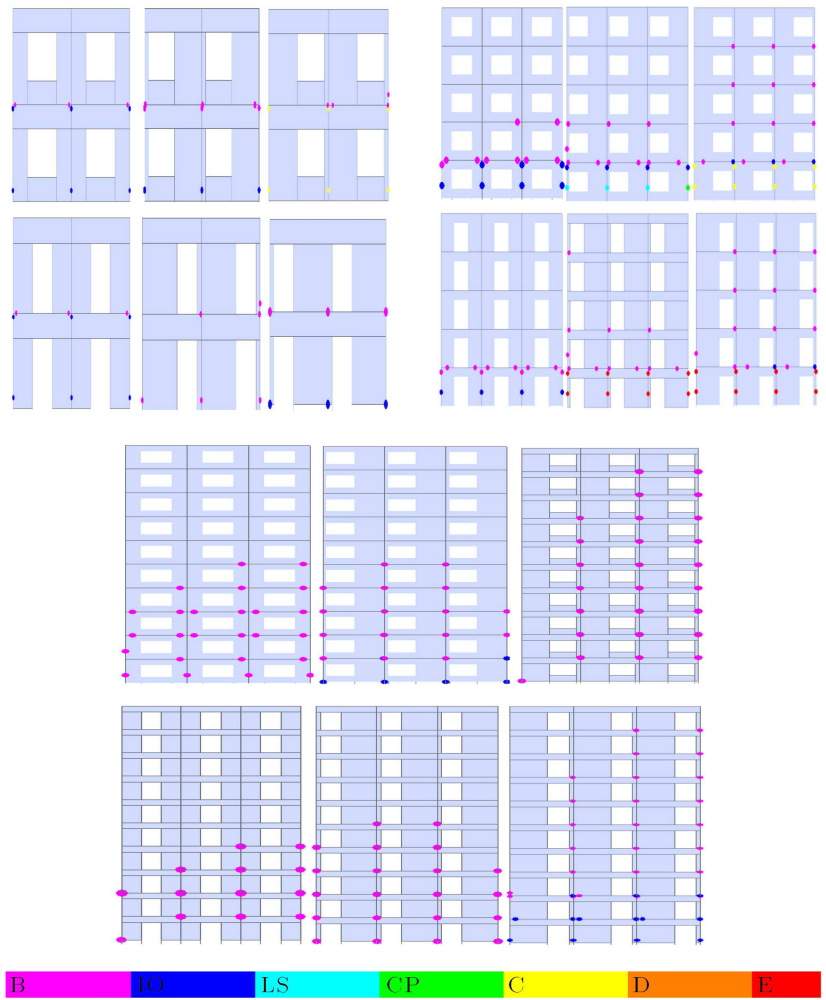

Figure 20. Hinges patterns for Structures 1, 2, and 3 with different locations of openings in the infill.

openings changes the events at which the plastic hinges patterns occur. For instance, the hinge patterns of infills with $50 \%$ openings are different from those of bare frame. Furthermore, the location and aspect ratio of opening influence the failure modes of the infilled frames depending on the dynamic characteristics of the structures.

\section{Conclusions}

In this paper, the seismic performance of $\mathrm{RC}$ frames with and without infills with special emphasis on the effects of openings was studied. The opening size of the infill had a significant influence on the fundamental period. Generally, it increased as the opening size increased, indicating that the decrease in stiffness was more significant than the decrease in mass. Results of pushover analysis showed an increase in initial stiffness and strength capacity of the infilled frame compared to the bare frame, despite the brittle failure modes of the masonry wall. The presence of masonry walls had a significant effect on the collapse mechanism observed. Dynamic characteristics proved to be important factors to consider, since they could notably influence the response parameters. Surprisingly, large-size openings in the infills substantially modified the behavior of infilled frames compared to the bare frame, where it was expected that the two behaviors would be close. The location and aspect ratio of openings were 
important parameters that should be considered when designing this type of structures.

\section{References}

1. Holmes, M. "Steel frame with brickwork and concrete infilling", ICE Proceedings, 19, pp. 473-478 (1961).

2. Mainstone, R.J. and Weeks, G.A. "The influence of a bounding frame on the racking stiffness and strengths of brick walls", SIBMAC Proceeding, Presented at the Second International Brick Masonry Conference, Building Research Station, England (1970).

3. Crisafulli, F.J. "Seismic behavior of reinforced concrete structures with masonry infills", Ph.D. Thesis, University of Canterbury, New Zealand (1997).

4. El-Dakhakhni, W.W., Elgaaly, M., and Hamid, A.A. "Three-strut model for concrete masonry-infilled steel frames", Journal of Structural Engineering, 129, pp. 177-185 (2003).

5. Samoila, D.M. "Analytical modeling of masonry infills", Acta Technica Napocensis: Civil Engineering \& Architecture, 55(2), pp. 127-136 (2012).

6. Asteris, P.G., Cotsovos, D.M., Chrysostomou, C.Z., Mohebkhah A., and Al-Chaar, G.K. "Mathematical micro modeling of infilled frames: State of the art", Engineering Structures, 56, pp. 1905-1921 (2013).

7. István, H. and Zsolt, H. "Comparison of experimental and analytical results on masonry infilled RC frames for cyclic lateral load", Periodica Polytechnica Civil Engineering, 59(2), pp. 193-208 (2015).

8. Ivan, R., Damir, M., and Vladimir, S. "Analytical modeling of masonry-infilled steel frames", Tehničkivjesnik, 23, pp. 115-127 (2016).

9. Dhanasekhar, M. and Page, A. "The influence of brick masonry infill properties on the behavior of infilled frames", ICE Proceedings, 81, pp. 593-605 (1986).

10. Mehrabi, A. and Shing, P.B. "Finite element modeling of masonry-infilled RC frames", Journal of Structural Engineering, 123, pp. 604-613 (1997).

11. Oliveira, D.V. and Lourenco, P.B. "Implementation and validation of a constitutive model for the cyclic behavior of interface elements", Computers \& Structures, 82, pp. 1451-1461 (2004).

12. Stavridis, A. and Shing, P.B. "Finite-element modeling of nonlinear behavior of masonry-infilled RC frames", Journal of Structural Engineering, 136, pp. 285-296 (2010).

13. Koutromanos, I., Stavridis, A., Shing, P.B., and Willam, K. "Numerical modeling of masonry-infilled RC frames subjected to seismic loads", Computers \& Structures, 89, pp. 1026-1037 (2011).

14. Manos, G.C., Soulis, V.J., and Thauampteh, J. "The behavior of masonry assemblages and masonry-infilled $\mathrm{R} / \mathrm{C}$ frames subjected to combined vertical and cyclic horizontal seismic-type loading", Advances in Engineering Software, 45, pp. 213-231 (2012).
15. Uva, G., Raffaele, D., Porco, F., and Fiore, A. "On the role of equivalent strut models in the seismic assessment of infilled RC buildings", Engineering Structures, 42, pp. 83-94 (2012).

16. Baloevic', G., Radnic', J., and Harapin, A. "Numerical dynamic tests of masonry-infilled RC frames", Engineering Structures, 50, pp. 43-55 (2013).

17. Ivo, C. and Bartolomeo, P. "A macro-element modeling approach of infilled frame structures", Computers and Structures, 143, pp. 91-107 (2014).

18. Chen, Xi. and Liu, Yi. "Numerical study of in-plane behaviour and strength of concrete masonry infills with openings", Engineering Structures, 82, pp. 226-235 (2015).

19. Yuen, Y.P. and Kuang, J.S. "Nonlinear seismic responses and lateral force transfer mechanisms of RC frames with different infill configurations", Engineering Structures, 91, pp. 125-140 (2015).

20. Enzo, M., Carmine, L., and Gaetano, D.S. "A simplified procedure for nonlinear static analysis of masonry infilled RC frames", Engineering Structures, 101, pp. 591-608 (2015).

21. Mehrabi, A.B., Shing, P.B., Schuller, M.P., and Noland, J.L. "Experimental evaluation of masonryinfilled RC frames", Journal of Structural Engineering, 122, pp. 228-237 (1996).

22. Mosalam, K.M., White, R.N., and Ayala, G. "Response of infilled frames using pseudo-dynamic experimentation", Earthquake Engng. Struct. Dyn, 27(6), pp. 589-608 (1998).

23. Al-Chaar, G., Issa, M., and Sweeney, S. "Behavior of masonry-infilled non ductile reinforced concrete frames", Journal of Structural Engineering, 128, pp. 1055-1063 (2002).

24. Alidad, H. and Khalid M.M. "Shake-table experiment on reinforced concrete structure containing masonry infill wall", Earthquake Engineering \& Structural Dynamics, 35, pp. 1827-1852 (2006).

25. Anil, Ö. and Altin, S. "An experimental study on reinforced concrete partially infilled frames", Engineering Structures, 29, pp. 449-460 (2007).

26. Blackard, B., Willam, K., and Mettupalayam, S. "Experimental observations of masonry infilled RC frames with openings", Thomas TC Hsu Symposium on Shear and Torsion in Concrete Structures, pp. 199222 (2009).

27. Stavridis, A., Koutromanos, I., and Shing, P.B. "Shake-table tests of a three-story reinforced concrete frame with masonry infill walls", Earthquake Engineering \& Structural Dynamics, 41, pp. 1089-1108 (2012).

28. Damodar Dubey, S.K. and Kute, S.Y. "Experimental investigation on the ultimate strength of partially infilled and steel-braced reinforced concrete frames", International Journal of Advanced Structural Engineering, 5(15), pp. 1-10 (2013). 
29. Lila M.A., Abouelezz, A.E.Y., and Faseal, F.E. "Behavior of masonry strengthened infilled reinforced concrete frames under in-plane load", HBRC Journal, 11(02), pp. 213-223 (2014).

30. Ahmed, S.A.T.E., Kotp Badr, M.R., and Ashraf, H. El-Z. "Effect of infill wall on the ductility and behavior of high strength reinforced concrete frames", $H B R C$ Journal, 10, pp. 258-264 (2014).

31. Srisanthi, V.G., Keshav, L., Poorna Kumar, P., and Jayakumar, T. "Finite element and experimental analysis of $3 \mathrm{~d}$ masonry compressed stabilised earth block and brick building models against earthquake forces", Periodica Polytechnica Civil Engineering, 58(3), pp. 255-265 (2014).

32. Hussein, O., Amr, A., Amr, A., and Metwaly, M. "Experimental and analytical investigation of the lateral load response of confined masonry walls", $H B R C$ Journal, 12(01), pp. 33-46 (2014).

33. Shan, S., Shuang, Li., Shiyu, Xu., and Lili, Xie. "Experimental study on the progressive collapse performance of RC frames with infill walls", Engineering Structures, 111, pp. 80-92 (2016).

34. Abdel-Gawad, A., Abdel-Mooty, M., Shaheen, H., and Issa, M.E. "Cyclic behaviour of masonry infilled RC frames with and without openings", 26th Conference on Our World in Concrete \& Structures: 27 - 28 August 2001, Singapore, pp. 777-786 (2001).

35. Goutam, M., Sudhir, K.J., and Eeri, M. "Lateral stiffness of masonry infilled reinforced concrete (RC) frames with central opening", Earthquake Spectra, 24(3), pp. 701-723 (2008).

36. Sachin, S. and Hemant, B.K. "Masonry infill RC frames with openings: Review of in-plane lateral load behaviour and modeling approaches", The Open Construction and Building Technology Journal, 6(1M9), pp. 126-154 (2012).

37. Ephraim, M.E. and Nwofor, T.C. "Composite behaviour of unbraced multi-storey reinforced concrete infilled frames based on modified one-strut model", Journal of Engineering Research and Applications, 5(4), Part -1, pp. 47-58 (April 2015).

38. Cetisli, F. "Effect of openings on infilled frame stiffness", GRADEVINAR, 67, pp. 787-798 (2015).

39. Khan, K.I. and Saim, R. "Seismic performance assessment of masonry infilled reinforced concrete (RC) frame structures", International Journal of Civil and Structural Engineering, 6(1), pp. 40-57 (2015).

40. RPA 2003 "Algerian seismic code", DTR-BC 248National Center for Applied Research in Parasismic Engineering (CGS), Algiers (2003).
41. CSI, SAP 2000, Ver 14.00, Integrated Finite Element Analysis and Design of Structures Basic Analysis Reference Manual, Berkeley (CA, USA): Computers and Structures INC (2009).

42. FEMA-356, Pre-Standard and Commentary for Seismic Rehabilitation of Buildings, Federal Emergency Federal Agency (2000).

43. Hughes, T.J.R., The Finite Element Method: Linear Static and Dynamic Finite Element Analysis, Dover (2000).

44. Kadid, A. and Boumerkik, A. "Pushover analysis of reinforced concrete frame structures", Asian Journal of Civil Engineering (Building and Housing), 9(1), pp. $75-83$ (2008).

45. Abhijeet, A.M., Nikhil, A.M., and Preeti, P.S. "Pushover analysis of reinforced concrete frame structures: A case study", International Journal of $A d$ vanced Technology in Engineering and Science, 2(10), pp. 118-128 (2014).

\section{Biographies}

Saleh Noui received the BSc degree from the University of Batna, Algeria, and the MSc degree from the National Polytechnic School of Algiers (ENP). Now, he is a PhD candidate in the National Polytechnic School of Algiers, Department of Civil Engineering, Algiers-Algeria. He is the author of numerous papers in journals and conferences. His main research interests include behavior of RC structures under seismic loadings and numerical modeling.

Abdelkrim Kadid received the BSc degree from the University of Constantine, Algeria, an MPhil degree from the University of Bath, UK, and a PhD degree from the University of Batna, Algeria. He is the author of numerous papers in journals and conferences. His main research interests include behavior of RC structures under seismic and blast loadings, and numerical modeling.

Abderrahim Bali received the BSc degree from the National Polytechnic School of Algiers (ENP), Algeria, and $\mathrm{PhD}$ degree from the University of Aston in Birmingham, GB. He is the author of numerous papers in journals and conferences. His main research interests include behavior of RC structures and materials under seismic loadings, and numerical and experimental modeling of materials. 